\section{Should body mass index be adjusted for relative sitting height in cross-sectional studies of chronic diseases in Japanese-Brazilians?}

\author{
Deve-se corrigir o valor do Índice de Massa \\ Corporal pelo comprimento relativo do tronco \\ em estudos de prevalência de doenças \\ crônicas em nipo-brasileiros?
}

\author{
Adriana Bouças Ribeiro ${ }^{1}$ \\ Suely Godoy Agostinho Gimeno 1 \\ Solange Andreoni 1 \\ Sandra Roberta Gouveia Ferreira ${ }^{1}$ \\ Japanese Brazilian Diabetes Study Group ${ }^{2}$
}

I Departamento de Medicina
Preventiva, Universidade
Federal de São Paulo,
São Paulo, Brasil.
2 Other members listed
at the end of the paper.
Correspondence
A. B. Ribeiro
Departamento de
Medicina Preventiva,
Universidade Federal
de São Paulo.
Rua Apeninos 95,
São Paulo, SP
O1533-000, Brasil.
adriboucas@osite.com.br

Abstract

The current article aimed to verify the degree of agreement in classification of nutritional status according to body mass index (BMI) and corrected body mass index (BMIc). Data were used from a cross-sectional study of Japanese-Brazilians. Statistical analysis provided prevalence rates for chronic diseases, kappa statistic, and Pearson's linear correlation coefficient. Some $5.9 \%$ of Japanese-Brazilians were discordant according to the BMI and BMIc classifications. The weighted kappa statistic $(0.94 ; p=0.000)$ indicated good agreement between the classifications. Similar prevalence rates for chronic diseases were obtained for individuals with excess weight classified by these two indices. Similar Pearson's linear correlation coefficients were obtained for these indices and waist circumference and body fat measurements. The results suggest that BMI correction for relative sitting height is probably unnecessary for these individuals.

Body Mass Index; Anthropometry; Chronic Diseases; Japanese-Brazilians

\section{Introduction}

Chronic non-communicable diseases are the principal cause of death in both developed and developing countries. This profile has been partially explained by rapid demographic and socioeconomic transformations 1 . In parallel there has been an increase in the number of individuals with excess weight 2,3 .

The prevalence of obesity, in turn, is associated with the urbanization and industrialization process, together with the increased availability of food and the reduction in physical activity in recent decades; it is both an independent risk factor and is associated with a series of other factors, like hypercholesterolemia, arterial hypertension, diabetes mellitus, and insulin resistance 4,5,6,7,8.

Anthropometry has been widely used in epidemiological studies to evaluate body composition, due to its low cost and simplicity, and the principal measurements are weight, height, circumferences, and skinfolds 9.

The so-called "Quetelet" index, or body mass index (BMI), or the ratio between weight (in $\mathrm{kg}$ ) and height squared (in meters), does not indicate body build but total body mass, but it is related to increased morbidity and mortality for values less than $18.5 \mathrm{~kg} / \mathrm{m}^{2}$ (infectious $/$ parasitic diseases) or greater than $25.0 \mathrm{~kg} / \mathrm{m}^{2}$ (chronic diseases, except cancers), thus justifying its use in the identification of individual nutri- 
tional status, with or without the combined use of other anthropometric measures 9,10,11,12.

Android-type or central obesity is characterized by major accumulation of fat in the abdominal region (waist) and is an important risk factor for cardiovascular diseases, type-2 diabetes mellitus, dyslipidemias, hyperinsulinemia, and arterial hypertension 13,14,15,16.

Various studies have confirmed the hypothesis that differences in body build account for the difference between BMI and body fat percentage, comparing different ethnic groups and genders 17,18,19,20. Possible explanations for the differences are the level of physical activity, relative length of the lower limbs, sitting height, or body build 21,22,23.

BMI is influenced by a series of factors, including the effect of body build, i.e., the variation in height caused by the variation between populations in trunk length or sitting height (SH) and length of lower limbs. To show these differences, Norgan \& Jones 24 corrected the BMI for relative sitting height (RSH), using a linear regression model separately for each gender. These authors observed that in the British population, corrected BMI values (BMIc), as compared to unadjusted values, increased $1 \mathrm{~kg} / \mathrm{m}^{2}$ or more in $33 \%$ of women and $10 \%$ of men and $2 \mathrm{~kg} / \mathrm{m}^{2}$ in $5 \%$ of women and $1 \%$ of men.

Norgan 22, Gurrici et al. 18, and Deurenberg et al. 19 discuss the relationship between trunk length and BMI. These authors observed that individuals with a slight body build presented a higher percentage of fat and not necessarily a higher skeletal mass.

There is evidence that the relationship between body fat and BMI varies according to ethnic group: Asians have a higher degree of adiposity for a given BMI as compared to Caucasians 23. Prevalence studies have shown that some ethnic groups have a relatively higher obesity risk than others, thereby predisposing to chronic diseases $17,25,26$.

Recent decades have witnessed an increase in the prevalence of diabetes mellitus 27 and dyslipidemias 28 in the Japanese population, with diet and the degree of physical activity considered as risk factors. In this context, excess weight can be an important risk factor for theses diseases, since various studies have shown (for the same period) an increase in the prevalence of overweight in Japanese adults 29,30,31,32. As compared to Caucasians, Japanese are shorter, stockier, with shorter lower limbs, more muscular, and thus present a higher degree of adiposity.

The high prevalence rates for diabetes mellitus, arterial hypertension, and dyslipidemias in the Japanese-Brazilian population 33 called attention to the need to verify the degree of agreement between nutritional status classifications according to BMI and BMIc among individuals with excess weight.

\section{Material and methods}

\section{Study design}

This was a cross-sectional study using data from the second phase of the epidemiological study conducted by the Japanese Brazilian Diabetes Study Group.

\section{Study population}

Japanese immigration to Brazil will have completed 100 years during the current decade. The immigration began in 1908 and extended until the early 1960s, with a break from 1941 to 1952. This fact allowed the coexistence of different generations and age groups. The world's largest nikkei population (Japanese and their descendents) outside of Japan lives in Brazil, with an estimated $70 \%$ having settled in the State of São Paulo.

After a demographic survey of this community in 1997, all first and second-generation individuals of both sexes and $\geq 30$ years of age were invited to participate in the second phase of the study $(n=1,751)$, of whom 1,330 agreed and were examined. There were 421 losses (24\%); of these, $64.6 \%$ were due to refusal, $13.5 \%$ to change of address, and $21.9 \%$ to death (both from 1993 to 1997 and from 1997 - with the census - and $1999 / 2000$ - data collection). Non-participants showed a higher proportion of men $<60$ years of age as compared to participants.

In the current study, for calculating and analyzing BMI, three individuals were excluded $(n=1,327)$ due to lack of information on anthropometric variables.

\section{Data collection}

The data were obtained from previously scheduled household interviews by trained professionals who applied standardized, previously tested questionnaires to obtain information on sociodemographic and cultural aspects, health, physical activity, and eating habits. During the household interviews, the appointment (place and date) was set for individuals to appear for the physical, clinical, and laboratory examination.

During the physical examination, anthropometric measures and blood pressure were 
taken by trained professionals. Laboratory exams included fasting blood sugar and blood sugar two hours after ingesting $75 \mathrm{~g}$ of glucose, total and partial cholesterol, and triglycerides.

Trunk length or sitting height was measured with a vertical ruler measuring up to 1.5 meters and accurate to $1 \mathrm{~cm}$. The subject sat erect on a table with hands resting on the thighs, feet hanging freely without touching the floor, and head erect and eyes on the horizon 34 . Relative sitting height (RSH) was obtained by dividing trunk length by height. Weight was measured with a Filizola digital scale weighing up to $200 \mathrm{~kg}$ and accurate to $100 \mathrm{~g}$. Subjects were weighed barefoot, with as little clothing as possible. Height was measured with a manual stadiometer attached to the wall, measuring up to $2 \mathrm{~m}$ and accurate to $1 \mathrm{~cm}$, with the subject standing erect, barefoot, heels together, head erect, eyes on the horizon, on a smooth, flat, rigid surface, with arms hanging at the side 11 . Waist circumference (WC) was measured with a nonextensible tape measure, with subjects standing and the measurement taken at the level of the umbilicus.

BMI was calculated by dividing current weight in $\mathrm{kg}$ by height in meters squared. Subjects were classified by BMI 35 as obese $(\geq 30 \mathrm{~kg} /$ $\mathrm{m}^{2}$ ), overweight (BMI $25-29.9 \mathrm{~kg} / \mathrm{m}^{2}$ ), normal (BMI 18.5-24.9kg/m²), and underweight (BMI < $\left.18.5 \mathrm{~kg} / \mathrm{m}^{2}\right)$.

BMIc was calculated as the sum of the expected BMI value for individuals with mean RSH value and the residue obtained from the simple linear regression model with observed BMI as the dependent variable and RSH as the independent variable 24 .

Reactance and resistance were estimated by the electric bioimpedance test (EBI), with a single frequency $(50 \mathrm{kHz})$ using a tetrapolar model EBI 101Q (RJL System, Clinton Township, USA). Subjects were fasting and had rested in a room for 15 to 20 minutes before the test. Subjects were asked to remove any metal objects before the test. The site where the electrodes were attached was disinfected previously with alcohol.

Systolic (SAP) and diastolic arterial pressure (DAP) were measured by trained physicians, using automatic digital sphygmomanometers model HEM712C (Omron, Bannockburn, USA). Subjects rested previously for 10 minutes in a calm environment, sitting with the upper member at the height of the heart. Three measurements were taken, and the final value used was the mean of the last two. Subjects were classified as hypertensive with DAP $\geq 90$ or SAP $\geq$ $140 \mathrm{mmHg}$ or in use of anti-hypertensive medication 36 .
Oral glucose tolerance test was performed in non-diabetic individuals and those reporting a previous diagnosis of diabetes mellitus, but with capillary glucose less than $200 \mathrm{mg} / \mathrm{dL}$. Participants on insulin therapy were excluded from this test. Plasma glucose was taken after fasting for at least ten hours prior to blood sampling, and then two hours after the oral glucose overload (75g). Plasma glucose was determined by the glucose oxydase method. Subjects with fasting plasma glucose $(\mathrm{FPG})<110 \mathrm{mg} / \mathrm{dL}$ and $2 \mathrm{~h}$ plasma glucose $<140 \mathrm{mg} / \mathrm{dL}$ were classified as normal, those with FPG $\geq 110$ and $<126 \mathrm{mg} / \mathrm{dL}$ and $2 \mathrm{~h}$ glucose $<140 \mathrm{mg} / \mathrm{dL}$ were classified as having abnormal fasting glucose (AFG), those with FPG $<126 \mathrm{mg} / \mathrm{dL}$ and $2 \mathrm{~h}$ glucose 140 $200 \mathrm{mg} / \mathrm{dL}$ were classified as having impaired glucose tolerance (IGT), and those with FPG $\geq$ $126 \mathrm{mg} / \mathrm{dL}$ or plasma glucose $2 \mathrm{~h}$ after ingesting $75 \mathrm{~g}$ of glucose $\geq 200 \mathrm{mg} / \mathrm{dL}$ or in use of medication for diabetes were classified as diabetic 37 .

Total and partial cholesterol and triglycerides were determined by enzymatic kits and processed in an automatic analyzer. Subjects were classified as presenting dyslipidemias with total cholesterol $>200 \mathrm{mg} / \mathrm{dL}$ or triglycerides $>150 \mathrm{mg} / \mathrm{dL}$ or high-density lipoprotein (HDL) $<40 \mathrm{mg} / \mathrm{dL}$ or low-density lipoprotein (LDL) > 130mg/dL 38 . The Castelli index was calculated as the ratio between total cholesterol total and HDL.

\section{Statistical analysis}

Point and interval prevalence was calculated with a $95 \%$ confidence interval $(95 \% \mathrm{CI})$, for glucose intolerance (diabetes mellitus, AFG, and IGT), arterial hypertension, and dyslipidemias for individuals with excess weight according to the BMI and BMIc categories 39,40,41. Mean Castelli index values for Japanese-Brazilians with overweight or obesity according to the BMI and BMIc categories were estimated by point and interval prevalence with $95 \%$ CI.

The degree of agreement between classifications of individuals according to the BMI and BMIc categories was evaluated using the weighted kappa statistic.

Correlations between the BMI and BMIc values and weight circumference, resistance, and reactance were studied to obtain Pearson's linear correlation coefficients (point and interval) 40,41.

Calculations and statistical analyses used STATA (Stata Corporation, College Station, USA) and Epidat 3.0 (http://dxsp.sergas.es/default. asp, Pan-American Health Organization/Xunta de Galícia). 


\section{Results}

Table 1 shows subjects according to BMI and BMIc values. Only 79 individuals (5.9\%) were discordant for classification by these indices. The kappa statistic value $(0.94 ; \mathrm{p}=0.000)$ indicates good agreement between the classifications, suggesting that BMI correction for relative sitting height is unnecessary.

Among discordant individuals, $88 \%(n=42)$ were classified by BMI as underweight or normal, while according to BMIc they were considered normal or overweight, respectively. The inverse situation was observed in discordant individuals classified by BMI as overweight or obese. Apparently, BMI correction for RSH overestimates the total body mass in leaner individuals and underestimates it for those with some degree of excess weight.
Of all the discordant individuals, $49.4 \%$ were males, $50.6 \%$ were less than 60 years of age, and only $17.7 \%$ were first-generation. The majority of these individuals were in the overweight and normal categories.

According to the current study, the BMIc values as compared to unadjusted BMI increased by $1 \mathrm{~kg} / \mathrm{m}^{2}$ or more in only $2.8 \%$ of men and $1.5 \%$ women and by $2 \mathrm{~kg} / \mathrm{m}^{2}$ in $0.3 \%$ of both women and men.

Table 2 shows the point and interval prevalence rates for diabetes, arterial hypertension, and dyslipidemias in individuals with overweight or obesity according to BMI and BMIc.

The prevalence rates for these diseases were similar among those considered overweight or obese according to the BMI and BMIc classifications. As already observed, according to the kappa statistic, this situation suggests

Table 1

Distribution of individuals according to body mass index (BMI) and corrected body mass index (BMIc).

\begin{tabular}{|c|c|c|c|c|c|}
\hline \multirow[t]{2}{*}{ BMIc } & \multicolumn{4}{|c|}{ BMI } & \multirow[t]{2}{*}{ Total } \\
\hline & Underweight & Normal & Overweight & Obese & \\
\hline Underweight & 33 & 5 & - & - & 38 \\
\hline Normal & 7 & 648 & 22 & - & 677 \\
\hline Overweight & - & 30 & 445 & 6 & 481 \\
\hline Obese & - & - & 9 & 123 & 132 \\
\hline Total & 40 & 683 & 476 & 129 & 1,328 \\
\hline
\end{tabular}

Weighted kappa statistic $=0.94 ; p=0.000$.

Table 2

Point and $95 \%$ confidence interval $(95 \% \mathrm{Cl})$ prevalence for diabetes, arterial hypertension, and dyslipidemias among individuals with overweight or obesity according to body mass index (BMI) and corrected body mass index (BMIc).

\begin{tabular}{|c|c|c|c|c|}
\hline \multirow[t]{2}{*}{ Diseases } & \multicolumn{2}{|c|}{ BMI } & \multicolumn{2}{|c|}{ BMIc } \\
\hline & $\begin{array}{c}\text { Overweight } \\
\text { Prevalence }(95 \% \mathrm{Cl})\end{array}$ & $\begin{array}{c}\text { Obesity } \\
\text { Prevalence }(95 \% \mathrm{Cl})\end{array}$ & $\begin{array}{c}\text { Overweight } \\
\text { Prevalence }(95 \% \mathrm{Cl})\end{array}$ & $\begin{array}{c}\text { Obesity } \\
\text { Prevalence }(95 \% \mathrm{Cl})\end{array}$ \\
\hline Diabetes & $45.3(40.8-49.9)$ & $60.5(51.5-68.9)$ & $45.1(40.6-49.7)$ & $58.3(49.4-66.8)$ \\
\hline AFG & $14.3(11.2-17.7)$ & $11.6(6.7-18.4)$ & $15.6(12.5-19.1)$ & $12.9(7.7-19.8)$ \\
\hline IGT & $27.5(23.5-31.7)$ & $22.5(15.6-30.6)$ & $25.8(21.9-29.9)$ & $24.2(17.2-32.5)$ \\
\hline Arterial hypertension & $44.0(39.5-48.6)$ & $48.0(39.2-57.0)$ & $43.6(39.1-48.2)$ & $47.0(38.2-55.8)$ \\
\hline Hypercholesterolemia & $67.9(63.5-72.1)$ & $65.9(57.0-74.0)$ & $67.2(62.8-71.3)$ & $68.9(60.3-76.7)$ \\
\hline Hypertriglyceridemia & $77.1(73.1-80.8)$ & $82.9(75.3-89.0)$ & $76.3(72.2-80.0)$ & 84.1 (76.7-89.9) \\
\hline Elevated LDL-c & $53.0(48.4-57.6)$ & $49.6(40.7-58.5)$ & $51.8(47.2-56.3)$ & $52.3(43.4-61.0)$ \\
\hline Decreased HDL-c & $14.5(11.4-17.9)$ & $10.9(6.1-17.5)$ & $15.2(12.1-18.7)$ & $9.8(5.3-16.3)$ \\
\hline
\end{tabular}

AFG = abnormal fasting glucose; IGT = impaired glucose tolerance; LDL-c = low-density lipoprotein cholesterol; $\mathrm{HDL}-\mathrm{c}=$ high-density lipoprotein cholesterol. 
that BMI correction for RSH did not alter the findings.

Mean Castelli index values in individuals classified as overweight by BMI and BMIc were, respectively, 4.49 (95\%CI: 4.487-4.492) and 4.50 (95\%CI: 4.497-4.502). A similar situation was observed in obese individuals [4.35 (95\%CI: 4.3394.360 ) versus 4.34 (95\%CI: 4.49 (95\%CI: 4.329 4.350)], also suggesting in relation to this index that BMI correction for RSH did not alter results.

Table 3 shows the values for the Pearson linear correlation coefficient between BMI and BMIc and waist circumference, resistance, and reactance. Similar Pearson linear correlation coefficient values were obtained for BMI and BMIc both for WC and resistance and reactance.

\section{Discussion}

The Asian population and especially the Japanese are known to present high prevalence rates for chronic diseases. An important risk factor for such diseases is usually obesity, especially of the android type, characterized by over-accumulation of fat in the abdominal region (waist). The question is that obesity is not present in the Asian population at levels that would explain the high susceptibility to chronic diseases. Japanese are also known to have a different body build from non-Asians. The Japanese have a longer relative sitting height, shorter lower limbs, shorter overall height, and a high degree of adiposity. This situation has led various researchers to propose correcting BMI for RSH. Norgan \& Jones 24 performed the correction using a linear regression model for the two sexes separately and observed that in the British population, BMIc values, as compared to unadjusted BMI, increased by $1 \mathrm{~kg} / \mathrm{m}^{2}$ or more in a considerable portion of men and women. In previous studies these authors had already shown that differences of 0.01 in RSH were associated with BMI differences of $0.9 \mathrm{~kg} / \mathrm{m}^{2} 21,22$.

According to the present study, BMIc values as compared to unadjusted BMI increased by $1 \mathrm{~kg} / \mathrm{m}^{2}$ or more in only $2.8 \%$ of men and $1.5 \%$ of women and by $2 \mathrm{~kg} / \mathrm{m}^{2}$ in $0.3 \%$ of women and men, a situation quite different from that observed in the British population by Norgan \& Jones 24 . In addition, in the current study, discordant individuals in the two classifications were mainly in the overweight and normal categories, possibly due to the higher number of individuals in these categories. The values obtained for the Pearson linear correlation coefficients between BMI (with and without correction) and WC, resistance, and reactance were
Table 3

Pearson's linear correlation coefficient for body mass index (BMI) and corrected body mass index (BMIc) and waist circumference, resistance, and reactance.

\begin{tabular}{lcccc}
\hline Variable & \multicolumn{2}{c}{ BMI } & \multicolumn{2}{c}{ BMIc } \\
& $r$ & $95 \% \mathrm{Cl}$ & $r$ & $95 \% \mathrm{Cl}$ \\
\hline Waist circumference & 0.83 & $0.80 ; 0.86$ & 0.84 & $0.82 ; 0.87$ \\
Resistance & -0.60 & $-0.63 ;-0.54$ & -0.56 & $-0.60 ;-0.50$ \\
Reactance & -0.26 & $-0.31 ;-0.21$ & -0.26 & $-0.30 ;-0.21$ \\
\hline
\end{tabular}

similar, indicating that BMI correction for RSH did not alter it relationship to either total body fat or localized abdominal fat.

Electrolytes are known to be excellent conductors of electric current while adipose tissue is a poor conductor due to the small amount of water. Due to the fact that the water content in the free fat mass is large, the latter can be predicted by estimates of total body water.

Reactance, in turn, as the opposition to current flow produced by the cell membrane, is an indicator of body fat, and resistance is the pure opposition to current flow across the body, and is the best predictor of free fat mass and total body water. This information indicated that BMI correction for RSH is volumetric and does not interfere in body fat as observed by reactance values.

In the current study, further evidence that for this population BMI correction for RSH does not aid in the identification of individuals at risk (i.e., with higher total body mass) was the absence of differences in Castelli index values according to the overweight and obesity categories by the two BMI values (adjusted and unadjusted). Individuals with excess weight $\left(\mathrm{BMI} \geq 25 \mathrm{~kg} / \mathrm{m}^{2}\right)$, as compared to normal individuals, are known to have a two-fold risk of hypertriglyceridemia, hypercholesterolemia, and reduced HDL-cholesterol (Ueshima et al., 1998, apud Inoue \& Zimmet 42 ).

According to Garn et al. 43, BMI has limitations, including the fact that it does not take lower limb length or sitting height into account. In the current study, BMI correction for RSH showed a few discordant individuals, but only $5.9 \%$ of the total. Another limitation of BMI is that depending on stature, it does not take the variations in different life cycles into account. In the Japanese-Brazilian population studied here, $42.7 \%$ were older than 60 , so that stature may have been underestimated 11 .

A limitation of the current study was the losses of some $24 \%(n=319)$, relatively more 
frequent in males and subjects under 60 . We believe that they had little influence on the results, since one can suppose that if all the individuals who did not participate in the study (total losses minus deaths) had been examined and were also discordant for the two classifications, the proportion of discordant individuals would still have been relatively low (approximately 20\%).

The results of this study suggest that correction of body mass index for relative sitting height in Japanese-Brazilians does not help identify individuals with higher total body mass and thus with greater risk for chronic diseases.

\section{Resumo}

O presente trabalho teve como objetivo verificar o grau de concordância entre as classificações do estado nutricional segundo os valores do índice de massa corporal (IMC) e o IMC corrigido (IMCC). Utilizou-se dados de estudo transversal realizado entre nipo-brasileiros. Na análise estatística dos dados foram obtidas as prevalências de doenças crônicas, a estatística kappa e o coeficiente de correlação linear de Pearson. Observouse que 5,9\% dos nipo-brasileiros foram discordantes quanto às classificações pelo IMC e IMCc. O valor da estatística kappa ponderado $(0,94 ; p=0,000)$ indicou boa concordância entre as classificações. Prevalências semelhantes de doenças crônicas foram obtidas para os indivíduos com excesso de peso classificados segundo estes dois índices. Valores semelhantes para os coeficientes de correlação linear de Pearson foram obtidos entre esses índices e as medidas de circunferência de cintura e as medidas de gordura corporal. Estes resultados sugerem que, provavelmente, a correção do IMC pelo comprimento relativo do tronco seja desnecessária para esses indivíduos.

Índice de Massa Corporal; Antropometria; Doenças Crônicas; Nipo-brasileiros

\section{Contributors}

A. B. Ribeiro was in charge of planning and elaborating the manuscript, data analysis, and drafting of the manuscript. S. G. A. Gimeno contributed to the planning and elaboration of the manuscript, data analysis, revision, and drafting of the manuscript. S. Andreoni participated in the data analysis. S. R. G. Ferreira participated in the planning and revision of the manuscript.

\section{Other members of the Japanese Brazilian Diabetes Study Group}

N. Barros Jr., M. A. Cardoso, R. C. Chaim, L. J. Franco, H. Harima, A. Hirai, A. T. Hirai, M. Y. Kikuchi, L. K. Matsumura, R. S. Moisés, K. Osiro, N. E. Tomita, and K. Wakisaka.

\section{References}

1. Popkin BM, Doak CM. The obesity epidemic is a worldwide phenomenon. Nutr Rev 1998; 56:10614.

2. Popkin B. The nutrition transition in low-income countries: an emerging crisis. Nutr Rev 1994; 52 : 285-98.

3. Monteiro CA, Mondini L, Souza ALM, Popkin BM. Da desnutrição para a obesidade: a transição nutricional no Brasil. In: Monteiro CA, organizador. Velhos e novos males da saúde no Brasil: a evolução do país e de suas doenças. São Paulo: Editora Hucitec; 1995. p. 247-55.

4. Mykkänen L, Laakso M, Pyörälä K. Association of obesity and distribution of obesity with glucose tolerance and cardiovascular risk factors in the elderly. Int J Obes 1992; 16:695-704.

5. Baumgartner RN, Heymsfield SB, Roche AF. Human body composition and the epidemiology of chronic disease. Obesity Res 1995; 3:73-95.

6. Pi-Sunyer FX. Health implications of obesity. Am J Clin Nutr 1991; 53 Suppl:1595S-603.

7. Manson JE, Colditz GA, Stampfer MJ, Willett WC, Rosner B, Monson RR, et al. A prospective study of obesity and risk of coronary heart disease in women. N Engl J Med 1990; 322:882-9.

8. Lerário DGD, Gimeno SG, Franco LJ, Iunes M, Ferreira SRG. Prevalence of weight excess and implications of abdominal fat distribution for the metabolic syndrome in Japanese - Brazilians. Rev Saúde Pública 2002; 36:4-11.

9. Willett WC. Nutritional epidemiology. 2nd Ed. New York: Oxford University Press; 1998.

10. Roche AF. Anthropometric methods: new and old, what they tell us. Int J Obes 1984; 8:509-23.

11. World Health Organization. Physical status: the use and interpretation of anthropometry. Geneva: World Health Organization; 1995. (WHO Technical Report Series, 854).

12. Deurenberg-Yap M, Schmidt G, van Staveren WA, Deurenberg $P$. The paradox of low body mass index and high body fat percentage among Chinese, Malays and Indians in Singapore. Int J Obes Relat Metab Disord 2000; 24:1011-7.

13. Hall JE, Crook ED, Jones DW, Wofford MR, Dubbert PM. Mechanisms of obesity - associated cardiovascular and renal disease. Am J Med Sci 2002; 324:127-37. 
14. Senti M, Bosch M, Aubo C, Elosua R, Masia R, Marrugat J. Relationship of abdominal adiposity and dyslipemic status in women with a common mutation in the lipoprotein lipase gene. The REGICOR investigators. Atherosclerosis 2000; 150:135-41.

15. Wei M, Gaskill SP, Haffner SM, Stern MP. Waist circumference as the best predictor of non-insulin dependent diabetes mellitus compared to body mass index, waist/hip ratio and other anthropometric measurements in Mexican Americans - a 7 year prospective study. Obes Res 1997; 5:16-23.

16. Ko GTC, Chan JCN, Cockram CS, Woo J. Prediction of hypertension, diabetes, dyslipidaemia or albuminuria using simple anthropometric indexes in Hong Kong Chinese. Int J Obes 1999; 23:1136-42.

17. Wang J, Thornton JC, Russell M, Burastero S, Heymsfield S, Pierson RN. Asians have lower body mass index but higher percent body fat than do whites: comparisons of anthropometric measurements. Am J Clin Nutr 1994; 60:23-8.

18. Gurrici S, Hartriyanti Y, Hautvast JGAJ, Deurenberg P. Differences in the relationship between body fat and body mass index between two different Indonesian ethnic groups: the effect of body build. Eur J Clin Nutr 1999; 53:468-72.

19. Deurenberg P, Deurenberg-Yap M, Wang J, Lin FP, Schmidt G. The impact of body build on the relationship between body mass index and percent body fat. Int J Obes 1999; 23:537-42.

20. Deurenberg P, Deurenberg-Yap M, Gurrici S. Asians are different from Caucasians and from each other in their body mass index/body fat per cent relationship. Obes Rev 2002; 3:141-6.

21. Norgan NG. Relative sitting height and the interpretation of the body mass index. Ann Hum Biol 1994; 21:79-82.

22. Norgan NG. Population differences in body composition in relation to the body mass index. Eur J Clin Nutr 1994; 48 Suppl 3:510-27.

23. Deurenberg P, Yap M, van Staveren WA. Body mass index and percent body fat: a meta-analysis among different ethnic groups. Int J Obes Relat Metab Disord 1998; 22:1164-71.

24. Norgan NG, Jones PRM. The effect of standardising the body mass index for relative sitting height. Int J Obes Relat Metab Disord 1995; 19:206-8.

25. Chandalia M, Abate N, Garg A, Stray-Gundersen J, Grundy SM. Relationship between generalized and upper body obesity to insulin resistance in Asian Indian men. J Clin Endocrinol Metab 1999; 84:2329-35.

26. Hill JO, Sidney S, Lewis CE, Tolan K, Scherzinger AL, Stam ER. Racial differences in amounts of visceral adipose tissue in young adults: the CARDIA (Coronary Artery Risk Development in Young Adults) study. Am J Clin Nutr 1999; 69:381-7.

27. Islam MM, Horibe H, Kobayashi F. Current trend in prevalence of diabetes mellitus in Japan, 19641992. J Epidemiol 1999; 9:155-62.

28. Okayama A, Ueshima H, Marmot MG, Elliott P, Yamakawa M, Kita Y. Changes in total serum cholesterol and other risk factors for cardiovascular diseases in Japan 1980-1989. Int J Epidemiol 1993; 22:1038-47.
29. Sakurai Y, Kono S, Shinchi K, Honjo S, Todoroki I, Wakabayashi K, et al. Relation of waist-hip ratio to glucose tolerance, blood pressure, and serum lipids in middle-aged Japanese males. Int J Obes Relat Metab Disord 1995; 19:632-7.

30. Liu L, Choudhury SR, Okayama A, Hayakawa T, Kita Y, Ueshima H. Changes in body mass index and its relationships to other cardiovascular risk factors among Japanese population: results from the 1980 and 1990 National Cardiovascular Surveys in Japan. Int J Epidemiol 1999; 9:163-74.

31. Horibe H. Trend of average height, weight and skinfolds in the Japanese. Diabetes Res Clin Pract 1990; 10 Suppl 1:S113-8.

32. Sakata K, Labarthe DR. Changes in cardiovascular disease risk factors in three Japanese national surveys 1971-1990. J Epidemiol 1996; 6:93-107.

33. Gimeno SGA, Ferreira SRG, Franco LJ, Hirai, AT, Matsumura L, Moisés RS. Prevalence and 7-year incidence of type II diabetes mellitus in a Japanese-Brazilian population: an alarming public health problem. Diabetologia 2002; 45:1635-8.

34. Frisancho AR. Anthropometric standards for the assessment of growth and nutritional status. Ann Arbor: University of Michigan Press; 1990.

35. World Health Organization. Obesity: preventing and managing the global epidemic. Geneva: World Health Organization; 1998.

36. Chobanian AV, Bakris GL, Black HR, Cushman WC, Green LA, Izzo JL, et al. The Seventh Report of the Joint National Committee on Prevention, Detection, Evaluation, and Treatment of High Blood Pressure: the JNC 7 report. JAMA 2003; 289:256072.

37. World Health Organization. Definition, diagnosis and classification of diabetes mellitus and its complications. Part 1: diagnosis and classification of diabetes mellitus. Geneva: World Health Organization; 1999.

38. Expert Panel on Detection, Evaluation and Treatment of High Blood Cholesterol in Adults. Executive Summary of the Third Report of The National Cholesterol Education Program (NCEP) Expert Panel on Detection, Evaluation, and Treatment of High Blood Cholesterol in Adults (Adult Treatment Panel III). JAMA 2001; 285:2486-96.

39. Snedecor GW, Cochran WG. Statistical methods. 8th Ed. Ames: Iowa State University Press; 1989.

40. Berquó E, Souza JMP, Gotlieb SLD. Bioestatística. São Paulo: EPU; 1986.

41. Armitage P, Berry G. Statistical Methods in Medical Research. 2nd Ed. Oxford: Blackwell Scientific Publications; 1987.

42. Inoue $S$, Zimmet $P$. The Asia-Pacific perspective: redefining obesity and its treatment. Melbourne: WHO Regional Office for the Western Pacific; 2000.

43. Garn SM, Leonard WR, Hawthorne VM. Three limitations of the body mass index. Am J Clin $\mathrm{Nu}-$ tr 1986; 44:996-7.

Submitted on $24 / \mathrm{Nov} / 2004$

Final version resubmitted on 23/Sep/2005

Approved on 27/Sep/2005 